\title{
VAŽNOST KOMUNIKACIJE U PROCESU SPAJANJA I PREUZIMANJA PODUZEĆA: EMPIRIJSKO ISTRAŽIVANJE U BELGIJI, ČEŠKOJ, FRANCUSKOJ, MAĐARSKOJ I REPUBLICI HRVATSKOJ
}

\author{
ROLE OF COMMUNICATION IN M\&A PROCESSES: \\ EMPIRICAL RESEARCH IN BELGIUM, CZECH REPUBLIC, \\ FRANCE, HUNGARY AND CROATIA
}

SAŽETAK: U suvremenome poslovnom svijetu poduzeća sve više koriste spajanja i preuzimanja kao mehanizam za strateško širenje, jačanje i održavanje njihovoga položaja na tržištu. Mnogi te transakcije vide kao relativno brz i učinkovit način za izlazak na nova tržišta i pristup novim tehnologijama. Ipak, uspjeh tih transakcija je neizvjestan. Sukladno brojnim istraživanjima od $50-75 \%$ transakcija spajanja i preuzimanja poduzeća doživi neuspjeh. Dok se dio neuspješnih spajanja i preuzimanja poduzeća može objasniti kroz djelovanje financijskih i tržišnih čimbenika, mnoštvo neuspješnih transakcija posljedica je zanemarivanja zaposlenika, koji su često naglašeni kao najvrednija imovina poduzeća. Iz toga se razloga u ovome radu istražuje važnost i uloga komunikacije sa zaposlenicima u procesu spajanja i preuzimanja poduzeća, kao i njen utjecaj na ishod transakcije. Empirijsko istraživanje provedeno je u Belgiji, Češkoj, Francuskoj, Mađarskoj i Republici Hrvatskoj na uzorku od 100 zaposlenika iz poduzeća koja su prošla kroz proces spajanja ili preuzimanja. Rezultati istraživanja sugeriraju kako pravodobna komunikacija u procesu spajanja i preuzimanja utječe na pozitivno prihvaćanje procesa od strane zaposlenika.

KLJUČNE RIJEČI: spajanja i preuzimanja poduzeća, komunikacija sa zaposlenicima, ponašanje zaposlenika, uspjeh spajanja i preuzimanja.

Morana Grgić, MBA, Atalian Global Services Croatia d.o.o., Hondlova 2, 10000 Zagreb, e-mail: morana. grgic@atalian.hr

* Doc. dr. sc. Davor Filipović, Ekonomski fakultet Sveučilišta u Zagrebu, Trg J. F. Kennedyja 6, 10000 Zagreb, e-mail: dfilipovic@efzg.hr

**** Karla Grgić, univ. bacc. oec., Ekonomski fakultet Sveučilišta u Zagrebu (studentica), Trg J. F. Kennedyja 6, 10000 Zagreb, e-mail: grgickarla@yahoo.com 


\begin{abstract}
In the modern business world companies more often use mergers and acquisitions in order to become stronger and more powerful competitors on the global market. This is known to be a quick and efficient way to enter new markets and access new technologies. However, the outcome of these transactions is unpredictable. According to numerous research, $50 \%$ to $75 \%$ of all mergers and acquisitions fail. While a part of these unsuccessful transactions can be explained by the effect of financial and market factors, a large number of unsuccessful transactions are due to the neglect of employees who are often pointed out as the company's most valuable asset. For that reason, this paper examines the importance of communication with employees in the process of a merger or acquisition, as well as its influence on the outcome of the transaction. Empirical research has been conducted in Belgium, Czech Republic, France, Hungary and Croatia on a sample of 100 employees from companies that have gone through the process of merger or acquisition. The results of the research suggest that timely communication during merger or acquisition has a positive impact on the employees.
\end{abstract}

KEY WORDS: mergers and acquisitions, communication with employees, employees' behavior, M\&A success.

\title{
1. UVOD
}

Spajanja i preuzimanja poduzeća posljedica su globalizacijskih procesa uslijed kojih poduzeća ulažu svoj kapital u druga poduzeća kako bi osvojila nova tržišta, smanjila troškove, povećala efikasnost, konkurentnost i dr. Među brojnim čimbenicima koji utječu na uspješnost procesa spajanja i preuzimanja poduzeća, komunikacija se može promatrati kao krucijalna varijabla. Otvorena i učestala komunikacija sa zaposlenicima te njihovo uključivanje u aktivnosti vezane za spajanje ili preuzimanje poduzeća temelj je uspješne provedbe transakcije. Zaposlenici su skloni pružati otpor organizacijskim promjenama, a to je posebno izraženo prilikom spajanja ili preuzimanja poduzeća. Učinkovita i pravodobna komunikacija predstavlja važan alat koji menadžmentu može biti od velike koristi tijekom spajanja odnosno preuzimanja poduzeća.

U ovome se radu pokušava dati odgovor na pitanje zašto rezultati spajanja i preuzimanja poduzeća često nisu u skladu s očekivanjima te koliko je važan utjecaj zaposlenika na sam ishod transakcije. Brojna istraživanja potvrđuju da je ljudski kapital ključan za efikasno upravljanje procesima spajanja i preuzimanja poduzeća. Većina spajanja i preuzimanja poduzeća prolazi kroz tri faze: fazu prije transakcije, sam proces spajanja ili preuzimanja te post-integracijsku fazu. Sve spomenute faze potrebno je što učinkovitije i efikasnije implementirati kako bi se došlo do stadija kada su ciljevi transakcije realizirani ili su unutar zadanoga cilja. Ti ciljevi mogu biti postignuti samo kroz zaposlenike, a do njih se dolazi formalnom i neformalnom komunikacijom. Stoga je potrebno komunikaciju prilagoditi fazi transakcije, a iznimno je bitno da je ona unaprijed planirana.

Upravo je iz toga razloga u okviru ovoga istraživanja razvijena i testirana hipoteza prema kojoj pravodobna komunikacija u procesu spajanja i preuzimanja utječe na pozitivno prihvaćanje procesa od strane zaposlenika. U radu se nakon eksplikacije komunikacije kao krucijalne varijable za uspjeh spajanja i preuzimanja naglašava utjecaj komunikacije na ponašanje zaposlenika za vrijeme transakcije. $U$ četvrtome dijelu rada prezentiraju se nalazi 
empirijskoga istraživanja, dok se u petome, posljednjemu dijelu rada, sintetiziraju zaključci provedenoga istraživanja.

\section{KOMUNIKACIJA KAO KRUCIJALNA VARIJABLA USPJEHA SPAJANJA I PREUZIMANJA}

Puno pozornosti posvećuje se pravnim, financijskim i operativnim elementima spajanja i preuzimanja poduzeća. Međutim, menadžeri koji su prošli kroz proces spajanja odnosno preuzimanja poduzeća prepoznaju da je u današnjoj ekonomiji, upravljanje ljudskim resursima pravi ključ za maksimiziranje vrijednosti transakcije.

Recentna empirijska istraživanja ističu kako od $50 \%$ do $75 \%$ transakcija spajanja i preuzimanja ne ostvari predviđene ciljeve. Popis mogućih razloga neuspjeha čini se beskrajnim, a neki od najčešće navođenih uključuju nerealna očekivanja, loše planiranje, gubitak talentirane radne snage, lošu komunikaciju, kulturološke sukobe, promjenljive vanjske uvjete, integracijske poteškoće (Schuler i Jackson, 2001.). Tradicionalno, smatra se da spajanja ne uspijevaju zbog racionalnih ekonomskih razloga, ali novije analitičke studije o performansama spajanja potvrđuju da najčešće ispitivane varijable, u financijskoj i strategijskoj literaturi, nisu ponudile značajna objašnjenja o ishodu spajanja (King, 2004.). Ljudski čimbenik je stoga sve više prepoznat kao ključan čimbenik. Smanjenje organizacijske privrženosti, morala i produktivnosti tipične su značajke za obje tvrtke koje provode spajanje (Klendauer, 2009.).

Stručnjaci koji upravljaju ljudskim potencijalima (HR) trebaju biti sposobni nositi se s brojnim izazovima. Najzahtjevniji izazovi s kojima se susreću hrvatski stručnjaci su upravo spajanja i preuzimanja poduzeća. Upravljanje ljudskim potencijalima igra ključnu ulogu u uspjehu odnosno neuspjehu spajanja i preuzimanja poduzeća. Uključivanje zaposlenika u najranijoj fazi planiranja može bitno utjecati na uspjeh spajanja ili preuzimanja (Fontaine, 2007., str. 2.).

Temeljem iskustva poduzeća koja su prošla proces spajanja i preuzimanja napravljen je model aktivnosti spajanja i preuzimanja koji ima tri faze (Schuler i Jackson, 2001.):

$>$ faza prije transakcije

faza spajanja odnosno preuzimanja (integracijska faza)

post-integracijska faza (stvaranje novoga entiteta).

Prema Keyu i Sheltonu ljudski čimbenik je najčešći razlog neuspjeha spajanja i preuzimanja te bi bilo poželjno da većina, ako ne i svi ljudi koji to žele, ostanu na svojim pozicijama na kraju integracijskoga razdoblja. To se najbolje postiže odabirom zaposlenika čiji tempo i narav odgovaraju načinu spajanja ili preuzimanja koje se provodi (Key i Shelton, 2000.). U istraživanju spomenutih autora kao ključni čimbenici uspjeha spajanja i preuzimanja navode se: zadržavanje ključnih talenata i menadžera, komunikacija sa zaposlenicima i integracija korporativnih kultura. 
Tablica 1. Ključne aktivnosti ljudskih resursa za uspjeh spajanja i preuzimanja poduzeća

\begin{tabular}{|c|c|}
\hline Ljudski čimbenik & \% \\
\hline Zadržavanje ključnih talenata & 76 \\
\hline Komunikacija sa zaposlenicima & 71 \\
\hline Zadržavanje ključnih menadžera & 67 \\
\hline Integracija korporativnih kultura & 51 \\
\hline
\end{tabular}

Izvor: Kay, I. T., Shelton, M. (2000) The people problem in mergers. The McKinsey Quarterly, No. 4, str. 28.

S obzirom na to da se komunikacija sa zaposlenicima ističe kao jedna od ključnih varijabli za uspjeh spajanja ili preuzimanja, menadžment o njoj treba promišljati strateški. Komunikacija sa zaposlenicima mora imati stratešku ulogu u organizaciji, s ciljem učinkovitoga obavljanja posla. Strateška uloga znači da komunikacija mora biti integrirana u strategiju (Argenti i suradnici, 2005.).

Mnogi menadžeri gledaju na komunikaciju sa zaposlenicima kao na „crnu kutiju“. Komunikacija je organizaciji ili sve (vizija, strategija, poslovno planiranje, menadžerski sastanci, tok informacija, menadžersko znanje itd.) ili ništa više nego objava kojom se namjerava zaposlenike informirati o novinama iz poduzeća (Barrett, 2002.). Učinkovita komunikacija sa zaposlenicima je „ljepilo“ koje drži organizaciju zajedno, a tijekom velikih promjena to ljepilo postaje od iznimne važnosti. Ono omogućuje provođenje nesmetanih operacija unutar organizacije i povezuje sve ostale procese u organizaciji kao što su strateško i poslovno planiranje procesa (Northup, 2006.).

Pravodobna komunikacija podrazumijeva otvoreno i izravno priopćavanje informacija te realnu procjenu budućih prilika i mogućih poteškoća kao što su, primjerice, nova sistematizacija radnih mjesta ili planovi za smanjenje broja zaposlenika. Komunikacija sa zaposlenicima u što ranijoj fazi spajanja ili preuzimanja smanjit će rizik od širenja glasina, nesporazuma ili pogrešnih očekivanja od strane pojedinih grupa ili pojedinaca. Komunikacija je u ovoj fazi od presudne važnosti, a menadžeri trebaju dobro vladati komunikacijskim i interpersonalnim vještinama kako bi ona bila uspješna (Appelbaum i suradnici, 2000.). Davanje mogućnosti zaposlenicima za sudjelovanjem u procesu integracije važan je čimbenik uspješnosti integracije u procesu spajanja i preuzimanja (Froese, 2010.). Sudjelovanje zaposlenika u aktivnostima vezanim za spajanja ili preuzimanja jamstvo je njihove suradnje i podrške u fazi koja slijedi neposredno po dovršetku samoga postupka. Sudjelovanje zaposlenika podrazumijeva razmjenu ideja, ukazivanje na potencijalne probleme koji kod njih izazivaju zabrinutost te davanje prijedloga i povratnih informacija. Istraživanja pokazuju da sudjelovanje zaposlenika u postupku odlučivanja umanjuje njihov otpor prema promjenama i čini ih spremnijima na uvažavanje potencijalnih razlika u korporativnoj kulturi i prihvaćanje njima uvjetovanih promjena (Appelbaum i suradnici, 2000.).

Komunikacija, kao jedna od najvažnijih varijabli za uspjeh preuzimanja, u žarištu je brojnih istraživanja. Iako postoje ograničenja u pogledu kvalitete i kvantitete informacija koje zaposlenici preuzetoga poduzeća trebaju posjedovati, komunikacija sa zaposlenicima je bitna kako bi se minimizirale negativne reakcije zaposlenika preuzetoga poduzeća (Nikandrou i suradnici, 2000.). U literaturi o provedbi procesa spajanja ili preuzimanja mogu se pronaći brojni savjeti o vrijednosti komuniciranja sa zaposlenicima te se naglašava da 
komunicirati treba što je češće moguće. Mnogi autori idu tako daleko da kažu da ne postoji takva stvar kao ,previše komunikacije“ (engl. overcommunicating) u spajanju ili preuzimanju poduzeća (Grgić, 2012.).

Česta komunikacija ne znači da menadžment treba komunicirati o svim detaljima preuzimanja, nego treba poticati komunikaciju o onome što potiče zabrinutost kod zaposlenika i što utječe na poljuljanost povjerenja u menadžment. Iako se smatra da sama komunikacija nije dovoljna da stvori povjerenje između zaposlenika i menadžmenta, nedostatak komunikacije može uzrokovati narušavanje povjerenja (Nikandrou i suradnici, 2000.).

Komunikacija treba biti iskrena i usmjerena na pitanja koja su od posebne važnosti za zaposlenike. Iskrena komunikacija od strane menadžmenta pomaže zaposlenicima da prihvate promjene koje su posljedica spajanja ili preuzimanja. Pružanje jasnih, dosljednih, suosjećajnih i novih informacija može utjecati na povećanje produktivnosti zaposlenika, a time i bolje poslovanje poduzeća nakon preuzimanja (Appelbaum i suradnici, 2000.).

Recentna istraživanja također ističu kako je komunikacija iznimno važna u post-integracijskoj fazi kako bi se postigli sinergijski učinci između preuzimatelja i poduzeća mete (Graebner i suradnici, 2017.). Pretpostavka je kako će veći stupanj interakcije rezultirati boljom koordinacijom i superiornijim poslovnim rezultatima preuzimatelja i poduzeća mete. Bresman, Birkinshaw i Nobel (1999.) su mjerili post-integracijsku komunikaciju između odjela za istraživanje i razvoj i identificirali pozitivnu povezanost s prijenosom tacitnog znanja. Reus i Lamont (2009.) su također identificirali pozitivnu vezu između komunikacije i uspješnosti preuzimanja koju su definirali kao kompozitnu varijablu profitabilnosti, tržišnoga udjela, opsega prodaje i razvoja novih proizvoda.

Allata i Singh (2011.) su istraživali post-integracijsku komunikaciju putem razmjene elektroničke pošte među pojedincima te su identificirali kako je u prvoj fazi post-integracijske komunikacije znatno češća komunikacija među pojedincima unutar istoga poduzeća (preuzimatelja ili poduzeća mete) nego među poduzećima. Također, zamijetili su kako se najviši stupanj komunikacije pojedinaca iz poduzeća preuzimatelja s pojedincima iz poduzeća mete postiže nakon otprilike dvije godine od trenutka preuzimanja, ali nakon čega slijedi smanjenje komunikacije.

Naposljetku važno je naglasiti ulogu komunikacije u prekograničnim spajanjima i preuzimanjima gdje kulturološke udaljenosti otežavaju komunikaciju među poduzećima što posljedično negativno djeluje na poslovne rezultate. Reus i Lamont (2009.) su identificirali kako kulturološka različitost naglašava važnost komunikacije u procesima spajanja i preuzimanja te kako je ulaganje u komunikaciju nužno kako bi se reducirali negativni učinci kulturoloških razlika u prekograničnim spajanjima i preuzimanjima.

\section{UTJECAJ KOMUNIKACIJE NA PONAŠANJE ZAPOSLENIKA}

Utjecaj komunikacije na ponašanje zaposlenika tijekom procesa spajanja ili preuzimanja sveprisutan je i značajno utječe na usvajanje novih korporativnih kultura, na promjene koje slijede nakon transakcije i razinu stresa zaposlenika. Procesi spajanja i preuzimanja povezani su s velikom količinom stresa koja se javlja kod zaposlenika. Dokazano je da se 
pružanjem relevantnih informacija zaposlenicima smanjuje nesigurnost te umanjuju negativni učinci koji utječu na dobrobit zaposlenika, odanost i povjerenje u menadžment (Stahl i suradnici, 2005.). Važno je naglasiti kako već sama najava spajanja i preuzimanja može kod zaposlenika uzrokovati nesigurnost, stres, apsentizam te smanjiti zadovoljstvo poslom i predanost. Schweiger i Denisi (1991.) su, među ostalim, identificirali kako realna komunikacija sa zaposlenicima može smanjiti neizvjesnosti i smanjiti vjerojatnost navedenih negativnih posljedica. Pravu i odgovarajuću komunikaciju je teško postići jer se komunikacijski proces susreće s brojnim potencijalnim zaprekama. Rješavanje nesigurnosti zaposlenika koja se javlja tijekom spajanja ili preuzimanja najbrže se može postići putem komunikacije. Iskrenost, otvorenost i izravnost u komunikaciji sa zaposlenicima od iznimne je važnosti (Appelbaum i suradnici, 2000.). Prema D’Aprix postoji sedam elemenata koji su bitni za formiranje komunikacijske strategije: informacije, ciljana publika, komunikacija „lice u lice“, otvorenost, istraživanje, tržište i radno mjesto te strategija. Posljednji element veže sve ostale kako bi se formirala strategija prije nego se krene u realizaciju (D’Aprix, 2009.)

Također, vrlo je važno odabrati pravo vrijeme za početak komunikacije, a to se postiže planiranjem prije početka procesa spajanja ili preuzimanja poduzeća. Međutim, prerana komunikacija nije poželjna zbog čestog nedostatka informacija, isto kao i zakašnjela komunikacija koja može rezultirati strahom i otporom zaposlenika, a onda i njihovim neprijateljskim djelovanjem zbog neistinitih glasina koje su prije došle do njih (Appelbaum i suradnici, 2000.).

Komunikacija je nužna kada je u pitanju upravljanje ljudskim resursima tijekom složenih organizacijskih promjena. Učinkovita komunikacija pomaže zaposlenicima da napuste prošlost i otvoreno krenu prema naprijed, omogućavajući organizaciji da opravda vrijednost transakcije što prije. Pravodobna, precizna i razumljiva komunikacija je ključna za uspjeh procesa spajanja i preuzimanja (Dauber, 2011.) Uspostavljanje odgovarajuće komunikacije također pomaže ublažiti druge rizike spajanja i preuzimanja poduzeća, kao što su gubitak ključnih talenata, smanjenje kvalitete usluge klijentu i smanjenje zadovoljstva klijenta, nedostatak povjerenja u menadžment i povećavanje otpora promjenama (Peterson i Voules, 2007.).

Učinkovita komunikacija je moćan alat za ubrzavanje organizacijskih promjena prilikom spajanja, preuzimanja i drugih poslovnih transakcija. Način na koji organizacija pomaže zaposlenicima da se nose s promjenama izravno utječe na poslovne rezultate. Ulaganje vremena, energije i resursa u komunikaciju, ne pomaže samo zaposlenicima da lakše prođu kroz integracijsku fazu nego i potiče veću produktivnost i motiviranost u fazi nakon integracije.

Komunikacijski proces treba započeti čim se donese odluka o spajanju ili preuzimanju i trebalo bi ga nastaviti kroz integracijsku fazu. Komunikacija između preuzimatelja i poduzeća mete mora biti značajna, konstantna i dosljedna te treba uključivati sve relevantne informacije za zaposlenike pogođene promjenama koju treba provoditi tijekom cijeloga procesa spajanja i preuzimanja, a ne da postane kontradiktorna s vremenom (Dauber, 2011.). Jedinstvene poruke moraju se priopćiti svim razinama novonastale organizacije. Informacije o tome što će se dogoditi, kada će se dogoditi i zašto se to događa mogu dugoročno ublažiti strah koji se obično javlja kad počnu kružiti razne glasine koje se često prošire velikom brzinom. Zaposlenici bi trebali imati priliku postavljati pitanja i treba im dati istiniti odgovor (Grantham, 2008.). 
Planiranje komunikacije u procesu spajanja i preuzimanja veliki je izazov za menadžment poduzeća. Čak i prije nego što je formalno spajanje ili preuzimanje u tijeku, zaposlenici često postaju svjesni neizravnih informacija ili osjete da je „nešto u zraku“. U ljudskoj je prirodi da žele znati što se događa. Ako osjete da se informacije čuvaju od njih, sasvim je razumljivo da će se početi osjećati uznemireno (Grantham, 2008.). Loša komunikacija može imate uzrok da se pojedinci više oslanjaju na glasine zbog nedostatka službenih informacija (Dauber, 2011.). Kada su ljudi nesigurni, počnu razmišljati o indikacijama koje su ispred njih. Stalnim interpretacijama indikacije postaju paranoje. Glasine s vremenom postaju tračevi. Produktivnost počinje padati kako zaposlenici troše vrijeme na rasprave o glasinama te se smanjuje njihova radna motivacija. Kao posljedica glasina, mnogi zaposlenici počinju napuštati poduzeće prije nego ih pogode loše vijesti (Grantham, 2008.).

Vrlo često, kada se financijski i pravni aspekti transakcije završe, post-integracijska komunikacija biva podcijenjena. No, post-integracijska faza komunikacije cilja na zaposlenike i kupce, što može biti od vitalnoga značaja za uspjeh same transakcije (Birnbach, 2010.). Efektivna komunikacija u post-integracijskoj fazi treba osigurati zajedničko razumijevanje vizije poduzeća nakon preuzimanja, pomoći ljudima da razumiju i prihvate promjene, zadržati usredotočenost organizacije na kupcima i produktivnosti, poticati željena ponašanja, promicati novu korporativnu kulturu, pomoći da se zadrže i motiviraju ključni talenti te kontroliraju glasine (Harrison, 2009.).

\section{EMPIRIJSKO ISTRAŽIVANJE O ULOZI KOMUNIKACIJE U PROCESU SPAJANJA I PREUZIMANJA PODUZEĆA}

\subsection{Metodologija empirijskoga istraživanja}

Za potrebe ovoga rada provedeno je empirijsko istraživanje na uzorku od 100 zaposlenika iz poduzeća koja su prošla kroz proces spajanja ili preuzimanja poduzeća. Kao mjerni instrument $\mathrm{u}$ empirijskome istraživanju korišten je anketni upitnik koji je poslan u 25 poduzeća iz Belgije, Češke, Francuske, Mađarske i Republike Hrvatske. Anketni upitnik se sastojao od dva dijela - prvi dio odnosio se na osnovne podatke o poduzeću i ispitaniku, dok se drugi dio odnosio na informacije o važnosti komunikacije u procesu spajanja i preuzimanja poduzeća. Sva analizirana poduzeća su velika poduzeća iz uslužne djelatnosti koja su u $82 \%$ slučajeva bila preuzeta, a kod preostalih $18 \%$ slučajeva došlo je do spajanja između poduzeća. Najveći dio sudionika istraživanja su zaposlenici do 40 godina (njih $50 \%$ ), od kojih su najzastupljeniji menadžeri srednje razine $(24 \%)$ i menadžeri nižih razina $(24 \%)$.

Cilj provedenoga empirijskog istraživanja, koje se temelji na dobivenim ekspertnim mišljenjima, je utvrditi važnost komunikacije u procesu spajanja i preuzimanja poduzeća. Prilikom analize rezultata istraživanja korištene su metode deskripcije i indukcije te inferencijalne statističke analize (z-test), korelacije i multiple regresije. 


\subsection{Rezultati empirijskoga istraživanja}

Empirijsko istraživanje započelo je testiranjem polazne hipoteze:

Pravodobna komunikacija u procesu spajanja i preuzimanja utječe na pozitivno prihvaćanje toga procesa od strane zaposlenika.

Pravodobna komunikacija odnosi se na onu komunikaciju koja započinje u ranoj fazi procesa spajanja odnosno preuzimanja poduzeća, a uključuje korištenje istinitih i jasnih informacija koje se odnose na budućnost zaposlenika u poduzeću (primjerice, nova sistematizacija radnih mjesta ili planovi za smanjenje broja zaposlenika). Pozitivno prihvaćanje procesa podrazumijeva ponašanje zaposlenika u poduzeću nakon spajanja ili preuzimanja koje se ne bi trebalo znatno promijeniti u odnosu na razdoblje prije preuzimanja posebno u segmentu pružanja većega otpora, povećanoga broja izostanaka s posla (bolovanje), zanemarivanja poslovnih obveza itd. U istraživanju nije pravljena distinkcija između procesa spajanja i preuzimanja jer je pravodobna komunikacija u većem broju postojećih empirijskih istraživanja potvrđena kao jednako važna za obje aktivnosti. U cilju testiranja polazne hipoteze ispitanicima istraživanja postavljeno je pitanje o tome kako je na njihovu reakciju o spajanju ili preuzimanju utjecao stav menadžmenta i način prezentiranja same transakcije. Od ukupnoga broja ispitanika 56 \% je mišljenja kako je stav menadžmenta i način prezentiranja transakcije pozitivno utjecao na njihovu reakciju o spajanju ili preuzimanju, dok je na $44 \%$ ispitanika stav menadžmenta negativno utjecao na njihovu reakciju.

Tablica 2. Deskriptivna statistika o reakciji ispitanika na spajanje ili preuzimanje

\begin{tabular}{|c|c|c|c|c|}
\hline & \multicolumn{3}{|c|}{ REAKCIJA NA SPAJANJE I PREUZIMANJE } \\
\hline & & Pozitivno & Negativno/Nebitno & z-test (z-score) \\
\hline \multicolumn{2}{|c|}{ Slabo $(1+2)$} & 23,2 & 34,1 & $-1,17$ \\
\hline \multicolumn{2}{|c|}{ Umjereno (3) } & 26,8 & 38,6 & $-1,23$ \\
\hline \multicolumn{2}{|c|}{ Jako (4+5) } & 50,0 & 27,3 & 2,21 \\
\hline \multirow{2}{*}{ Total } & $\mathrm{N}$ & 56 & 44 & \\
\hline & $\%$ & 56,0 & 44,0 & \\
\hline
\end{tabular}

Izvor: istraživanje autora.

U cilju testiranja hipoteze također je napravljen i regresijski model kojime se provjeravao utjecaj pojedinih varijabli u prihvaćanju procesa spajanja i preuzimanja od strane zaposlenika (tablica 3.). 
Tablica 3. Multipla regresija

\begin{tabular}{|l|c|c|c|c|c|}
\hline \multirow{2}{*}{$\begin{array}{c}\text { Razina prihvaćanja procesa } \\
\text { spajanja odnosno preuzimanja } \\
\text { poduzeća na početku procesa }\end{array}$} & \multicolumn{2}{|c|}{$\begin{array}{c}\text { Nestandardi- } \\
\text { zirani koefici- }\end{array}$} & $\begin{array}{c}\text { Standardi- } \\
\text { zirani koe- } \\
\text { ficijenti }\end{array}$ & \multirow{2}{*}{ t } & \multirow{2}{*}{ Značajnost } \\
\cline { 2 - 5 } & $\begin{array}{c}\text { St. } \\
\text { greška }\end{array}$ & Beta & & \\
\hline (Konstanta) & 3,592 & 0,569 & & 6,315 & 0,000 \\
\hline Bili smo dovedeni pred gotov čin & $-0,062$ & 0,067 & $-0,075$ & $-0,928$ & 0,356 \\
\hline $\begin{array}{l}\text { Mislio sam da će nastupiti velike } \\
\text { promjene u poduzeću }\end{array}$ & $-0,013$ & 0,086 & $-0,013$ & $-0,155$ & 0,877 \\
\hline Bojao sam se otkaza & $-0,003$ & 0,095 & $-0,003$ & $-0,029$ & 0,977 \\
\hline $\begin{array}{l}\text { Bojao sam se promjene radnog } \\
\text { mjesta }\end{array}$ & $-0,002$ & 0,081 & $-0,003$ & $-0,029$ & 0,977 \\
\hline Bojao sam se snižavanja plaće & $-0,180$ & 0,082 & $\mathbf{- 0 , 2 1 9}$ & $\mathbf{- 2 , 2 0 8}$ & 0,030 \\
\hline $\begin{array}{l}\text { Bojao sam se kako ću se slagati s } \\
\text { novim menadžerom }\end{array}$ & $-0,122$ & 0,070 & $\mathbf{- 0 , 1 4 6}$ & $\mathbf{- 1 , 7 5 1}$ & 0,083 \\
\hline $\begin{array}{l}\text { Iz menadžmenta nisu došle } \\
\text { sve informacije o spajanju ili } \\
\text { preuzimanju }\end{array}$ & $-0,210$ & 0,066 & $\mathbf{- 0 , 2 4 3}$ & $\mathbf{- 3 , 1 9 7}$ & 0,002 \\
\hline $\begin{array}{l}\text { Kružilo je puno glasina o spajanju u } \\
\text { koje sam vjerovao }\end{array}$ & $-0,001$ & 0,061 & $-0,001$ & $-0,017$ & 0,987 \\
\hline $\begin{array}{l}\text { U mojem poduzeću postojala je } \\
\text { pravodobna komunikacija }\end{array}$ & 0,196 & 0,109 & $\mathbf{0 , 1 9 5}$ & $\mathbf{1 , 7 8 8}$ & 0,077 \\
\hline $\begin{array}{l}\text { Proces spajanja odnosno } \\
\text { preuzimanja pozitivno sam } \\
\text { prihvatio }\end{array}$ & 0,587 & 0,110 & $\mathbf{0 , 5 2 2}$ & $\mathbf{5 , 3 3 2}$ & 0,000 \\
\hline
\end{tabular}

Izvor: istraživanje autora.

Iz tablice 3. razvidno je da na prihvaćanje procesa spajanja i preuzimanja od strane zaposlenika najviše utječe njihov pozitivan stav prema samome procesu te pravodobna komunikacija za vrijeme procesa spajanja ili preuzimanja odnosno informiranje zaposlenika o transakciji na samome početku procesa. Prethodno navedeni zaključci inicirali su statističku provjeru povezanosti pravodobne komunikacije s pozitivnim prihvaćanjem procesa spajanja ili preuzimanja. Korelacijska analiza prikazana je u tablici 4.

Tablica 4. Korelacija između pravodobne komunikacije i pozitivnoga prihvaćanja procesa spajanja ili preuzimanja od strane zaposlenika

\begin{tabular}{|c|l|c|}
\hline \multicolumn{3}{|c|}{ Proces spajanja odnosno preuzimanja pozitivno prihvaćen } \\
\hline \multirow{2}{*}{$\begin{array}{c}\text { Postojanje pravodobne } \\
\text { komunikacije }\end{array}$} & Pearson-ova korelacija & $\mathbf{0 , 6 0 3}$ \\
\cline { 2 - 3 } & Sig. (2-kračna) & 0,000 \\
\cline { 2 - 3 } & $\mathrm{N}$ & 100 \\
\hline
\end{tabular}

Izvor: istraživanje autora. 
Rezultati korelacijske analize sugeriraju kako postoji jaka korelacija 0,603 između pravodobne komunikacije i pozitivnoga prihvaćanja samoga procesa spajanja i preuzimanja. S obzirom na to da postoji jaka korelacija između pravodobne komunikacije u procesu spajanja i preuzimanja pozitivnoga prihvaćanja samoga procesa od strane zaposlenika te uzimajući u obzir rezultate regresijske analize može se prihvatiti hipoteza prema kojoj pravodobna komunikacija u procesu spajanja i preuzimanja utječe na pozitivno prihvaćanje toga procesa od strane zaposlenika.

\section{ZAKLJUČAK}

Fenomen spajanja i preuzimanja poduzeća dugo je prisutan u poslovnome svijetu čiji je utjecaj na oblikovanje korporativne scene vrlo značajan, a poznaje samo jedno - konstantan i brz rast. U razvijenome svijetu ovakav oblik transakcija postao je svakodnevnica. Utjecaj globalizacije, tehnoloških inovacija te ukidanje državnih granica omogućili su poduzećima i potrošačima da prevladaju zemljopisne zapreke te putem transakcija spajanja i preuzimanja postanu konkurentni na međunarodnim tržištima u vrlo kratkome roku. Na taj način multinacionalna poduzeća alociraju svoje resurse izvan nacionalnih granica kako bi osvojila nova tržišta, smanjila troškove i povećala efikasnost.

Iako mnogi ovakve transakcije vide kao relativno brz i učinkovit način za proširenje na nova tržišta, njihov uspjeh nipošto nije osiguran. Upravo suprotno, prema raznim istraživanjima čak 50 - $75 \%$ transakcija spajanja i preuzimanja poduzeća doživi neuspjeh. Dok se neki neuspjesi mogu objasniti putem financijskih i tržišnih čimbenika, značajan broj njih rezultat je zanemarivanja ljudskoga čimbenika, upravo onoga kojeg mnogi nazivaju najvrednijom imovinom poduzeća. Istraživanja potvrđuju da je ljudski kapital ključan za učinkovito upravljanje spajanjima i preuzimanjima. Upravo je iz toga razloga u okviru ovoga istraživanja razvijena i testirana hipoteza prema kojoj pravodobna komunikacija u procesu spajanja i preuzimanja utječe na pozitivno prihvaćanje procesa od strane zaposlenika.

U cilju testiranja hipoteze provedeno je empirijsko istraživanje u Belgiji, Češkoj, Francuskoj, Mađarskoj i Republici Hrvatskoj na uzorku od 100 zaposlenika iz poduzeća koja su prošla kroz proces spajanja ili preuzimanja. Rezultati istraživanja sugeriraju kako pravodobna komunikacija u procesu spajanja i preuzimanja utječe na pozitivno prihvaćanje procesa od strane zaposlenika. Pravodobna komunikacija sa zaposlenicima, koja podrazumijeva otvoreno i izravno priopćavanje informacija te komunikacija koja započinje u najranijoj fazi utječe na smanjenje rizika od širenja glasina, nesporazuma ili pogrešnih očekivanja od strane pojedinih grupa ili pojedinaca.

Promatrajući procese spajanja i preuzimanja iz raznih perspektiva, bez obzira na njihovu veličinu ili opseg promjena koje donose, neupitno je da su sinonimi za promjene te destabilizirajući događaji koji utječu na mnoge ljude. Upravo zbog navedenoga, potrebno je vrlo pozorno pristupiti aspektu ljudskih potencijala, koji produciraju razne, uglavnom negativne promjene ponašanja. U ljudskoj je naravi i da se javlja strah kod nepoznatih situacija te da su zaposlenici skloni pružati otpor pred nepoznatim. Da bi se minimizirao strah, potrebno je zaposlenicima što bliže predočiti sam proces, za što je nužna pravodobna komunikacija prožeta istinitim i jasnim informacijama. Davanjem jasnih, dosljednih i činjeničnih 
informacija na razne načine povećat će suočavanje zaposlenika sa stresom, što će zauzvrat povećati njihovu produktivnost. Učestala komunikacija prije i nakon spajanja odnosno preuzimanja poduzeća preduvjet je za izgradnju povjerenja.

Uloga komunikacije u procesu strategijskoga spajanja i preuzimanja poduzeća od iznimne je važnosti za ishod same transakcije. Pravodobnom komunikacijom, onom koja započinje u najranijoj fazi procesa, a koristi se istinitim i jasnim informacijama, može se utjecati na pozitivno prihvaćanje procesa od strane zaposlenika. Sukladno tome, pravodobnom komunikacijom zaposlenici se uključuju u proces spajanja odnosno preuzimanja, na način da im je omogućena razmjena ideja, ukazivanje na potencijalne probleme koji kod njih izazivaju zabrinutost te davanje prijedloga i povratnih informacija. Takav način komunikacije sa zaposlenicima rezultirat će manjim pružanjem otpora zaposlenika, što za posljedicu može imati uspješnije poslovanje poduzeća nakon spajanja ili preuzimanja.

Buduća istraživanja uloge komunikacije u procesu spajanja i preuzimanja poduzeća trebala bi se usredotočiti na komunikacijske prakse i alate te kako oni utječu na dinamiku spajanja i preuzimanja. Zanimljivo bi bilo promatrati komunikaciju s medijima ili pak komunikaciju s različitim interesno-utjecajnim skupinama gdje korporacije nastoje opravdati svoje akcije odnosno dobiti legitimitet od različitih interesno-utjecajnih skupina. U budućim istraživanjima bilo bi važno identificirati kako se menadžeri nose s reakcijama na tržištu kapitala i kako komunikacijskim strategijama upravljaju internim i eksternim interesno-utjecajnim skupinama u procesu spajanja i preuzimanja.

\section{LITERATURA:}

1. Allata, J. T., Singh, H. (2011). Evolving communication patterns in response to an acquisition event. Strategic Management Journal, Vol. 32, No. 10, str. 1099-1118.

2. Appelbaum, S. H., Gandell, J., Yortis, H., Proper, S., Jobin, F. (2000). Anatomy of a merger: behavior of organizational factors and processes throughout the pre-duringpost-stages (part1). Management Decisions, Vol. 38, No. 9, str. 649-662.

3. Argenti, P. A., Howell, R. A., Beck, K. A. (2005). The strategic communication imperative. MIT Sloan Management Review, Vol. 46, No. 3, str. 82-89.

4. Barrett, D. J. (2002). Change communication: using strategic employee communication to facilitate major change. Corporate Communication: An International Journal, Vol. 7, No. 4, str. 219-231.

5. Birnbach, N. (2010). Three Stages of Merger Communication. CW Bulletin.

6. Bresman, H., Birkinshaw, J., Nobel, R. (1999). Knowledge transfer in international acquisitions. Journal of International Business Studies, Vol. 30, No. 3, str. 439-462.

7. D'Aprix, R. (2009). The credible company: Communicating with today's skeptical workforce. San Francisco: Jossey-Bass.

8. Dauber, D. (2011). Hybridization in mergers and acquisitions. Doctoral thesis, WU Vienna University of Economics and Business.

9. Filipović, D. (2011). Modeliranje egzogenih i endogenih varijabli organizacije za uspješno preuzimanje poduzeća. Doktorska disertacija, Zagreb: Ekonomski fakultet. 
10. Filipović, D. (2012). Izazovi integracijskih procesa: rast poduzeća putem spajanja, preuzimanja i strateških saveza. Zagreb: Sinergija.

11. Froese, F. J. (2010). Success and failure in managing foreign acquisitions in South Korea and Japan: Lessons from Renault, General Motors, and Daimler Chrysler. Global Business and Organization Excellence, Vol. 30, No. 1, str. 50-59.

12. Fontaine, C. W. (2007). Mergers \& Acquisitions: Understanding the Role of HRM, Northeastern University.

13. Graebner, M. E., Heimeriks, K. H., Huy, Q. N., Vaara, E. (2017). The process of post-merger Integration: a review and agenda for future research. Academy of Management Annals, Vol 11, No. 1, str. 1-32.

14. Grantham, S. (2008). Employee Communication for the Best Post-Merger Outcome, IABC: CW Bulletin Grantham. Dostupno na: www.iabc.com/cwb/archive/2008/0508/ Grantham.htm.

15. Grgić, M. (2012). Važnost komunikacije u procesu strategijskog spajanja i preuzimanja poduzeća. Specijalistički rad. Zagreb: Ekonomski fakultet.

16. Harrison, K. (2009). Good communication is essential for successful mergers and acquisitions. Dostupno na http://www.cuttingedgepr.com/articles/changecomm_good_comm.aspž.

17. Kay, I. T., Shelton, M. (2000). The people problem in mergers. The McKinsey Quarterly, No. 4.

18. King, D. R., Dalton, D. R., Daily, C. M., Covin, J. G. (2004). Meta-analyses of Post-acquisition Performance: Indications of Unidentified Moderators. Strategic Management Journal, Vol. 25, No. 2, str. 187-200.

19. Klendauer, R. (2009). Organizational justice and managerial commitment in corporate mergers. Journal of Managerial Psychology, Vol. 24, No. 1, str. 29-45.

20. Nikandrou, I., Papalexandris, N., Bourantas, B. (2000). Gaining employee trust after acquisition: Implications for managerial action. Employee Relations, Vol. 22, No. 4, str. 334-355.

21. Northup, T. (2006). Effective Communication: A necessity for a successful organization. Leadership Management Group.

22. Peterson, L., Voules S. (2007). Reflection on M\&A, The Human Capital Dimension. New York: Mercer Human Resource Consulting.

23. Reus, T. H., Lamont, B. T. (2009). The double-edged sword of cultural difference in international acquisitions. Journal of International Business Studies, Vol. 40, No. 8, str. 1298-1316.

24. Schuler, R., Jackson, S. (2001). HR Issues and activities in mergers and acquisitions, European Management Journal, Vol. 19, No. 3, str. 239-253.

25. Schweiger, D. M., Denisi, A. S. (1991). Communication with employees following a merger: A longitudinal field experiment. Academy of Management Journal, Vol. 34, No. 1 , str. 110-135.

26. Stahl, G., Kremershof, I., Larsson, R. (2005). Trust Dynamics in Mergers and Acquisition: A Case Survey. Insead, str. 1-43. 